\title{
Kegiatan Eksplorasi Mengukur Tanaman pada anak dalam Meningkatkan Kecerdasan Logis Matematis
}

\author{
Dian Umami ${ }^{1}$, Heri Hidayat ${ }^{2}$ \\ 1, 2, Pendidikan Islam Anak Usia Dini, Universitas Islam Negeri Sunan Gunung Djati \\ Bandung \\ Jalan Soekarno Hatta Kel. Cimencrang, Gedebage Kota Bandung, Jawa Barat, Indonesia \\ Email: Dianumami00@gmail.com ${ }^{1}, \underline{\text { Herihidayats3@gmail.com }}{ }^{2}$
}

Naskah diterima: 17 November 2019, direvi: 17 Maret 2020, diterbitkan: 31 Maret 2020

\begin{abstract}
Abstrak
Penelitian ini bertujuan untuk menganalisis kegiatan eksplorasi mengukur tanaman dalam meningkatkan kecerdasan logis-matematis pada kelompok B. Penelitian menggunakan metode campuran/ mixed method dengan pendekatan data kualitatif dan data kuantitatif. Jenis penelitian menggunakan model penelitian tindakan kelas yang bersifat kolaboratif. Subjek penelitian adalah siswa kelompok B. Proses pelaksanaan kegiatan eksplorasi mengukur tanaman ini adalah suatu pembelajaran yang mengombinasikan kegiatan sains dan matematika. Hasil penelitian menunjukan bahwa sebelum diterapkan kegiatan eksplorasi mengukur tanaman rata-rata sebesar 67,77\% dengan kriteria kurang. Setelah penerapan kegiatan eksplorasi mengukur tanaman kecerdasan logis matematis pada pembelajaran mengalami peningkatan yang cukup baik dalam setiap siklusnya. Hal ini dapat dilihat dari aktivitas guru pada siklus I diperoleh rata-rata sebesar 73,91\% termasuk kualifikasi baik, dan pada siklus II diperoleh rata-rata sebesar 95,46\% termasuk kualifikasi sangat baik dan berhasil. Aktivitas anak pada siklus I diperoleh rata-rata sebesar 71,045\% termasuk kualifikasi baik. Pada siklus II diperoleh rata-rata 85,96\% termasuk kualifikasi sangat baik. Selain itu kecerdasan logis matematis anak pada kegiatan eksplorasi mengukur tanaman pada siklus I diperoleh rata-rata sebesar 75,35\% dengan kriteria baik. Pada siklus II diperoleh rata-rata 89,17\% termasuk kriteria sangat baik. Dengan demikian kegiatan eksplorasi mengukur tanaman dapat meningkatkan kecerdasan logis matematis pada kelompok B.
\end{abstract}

Kata kunci:Eksplorasi, Kecerdasan Logis matematis , Mengukur Tanaman 


\section{Abstract}

This study aims to analyze the exploration activities of measuring plants in increasing logical-mathematical intelligence in group B. The study uses a mixed method with qualitative and quantitative data approaches. This type of research uses a collaborative classroom action research model. The subject of the research was group B students. The process of carrying out exploratory activities measuring plants was a study that combined science and mathematics activities. The results showed that prior to the exploration activities applied the plant measured an average of $67.77 \%$ with less criteria. After the application of exploration activities measuring plants logical mathematical intelligence on learning has increased quite well in each cycle. This can be seen from the activities of teachers in the first cycle obtained an average of $73.91 \%$ including good qualifications, and the second cycle obtained an average of $95.46 \%$ including very good and successful qualifications. Children's activities in the first cycle obtained an average of 71,045\% including good qualifications. In cycle II an average of $85.96 \%$ was obtained, including a very good qualification. Besides mathematical logical intelligence of children in exploration activities measuring plants in the first cycle obtained an average of $75.35 \%$ with good criteria. In cycle II an average of $89.17 \%$ was obtained, including very good criteria. Thus exploratory activities measuring plants can increase mathematical logical intelligence in group $B$.

\section{Keywords: Exploration, Mathematical Logical Intelligence, Measuring Plant}

\section{Pendahuluan}

Pendidikan pada anak merupakan suatu bentuk wahana yang memberikan pembelajaran demi terwujudnya pertumbuhan dan perkembangan anak. Kegiatan pengembangan aspek-aspek pembelajaran pada anak usia dini dapat dilakukan melalui berbagai metode pembelajaran dan pembiasaan baik kegiatan di dalam kelas, di luar kelas, bermain dengan benda nyata, melakukan percobaan-percobaan kecil (sains) bahkan bercocok tanam. (Andayani, 2013:6).

Menurut Mursyid (2015:22) metode pembelajaran "bermain sambil belajar" bertujuan untuk mengembangkan keimanan, ketakwaan, akhlakul karimah dalam berdaya pikir, berdaya cipta, berbahasa, berketerampilan dan mengapresiasi seni baik seni musik, tari maupun suara serta dalam kegiatan bermain dan berinteraksi sosial anak sehari-hari. Anakanak lebih senang dan tidak cepat bosan melakukan setiap kegiatan yang ditemukannya.

Belajar melalui kegiatan bermain mampu membuat konsentrasi anak lebih lama, sebagaimana menurut Hurlock anak usia dini memiliki daya konsentrasi yang singkat yaitu 10-15 menit. Dalam belajar anak usia dini memerlukan perantara atau yang disebut dengan 
media pembelajaran. Contohnya dalam kegiatan mengenal huruf, mengenal angka, mengenal konsep-konsep yang lain sesuai tematik sangat memerlukan media yang bisa menarik perhatian anak (Suryana, 2016:10).

Peningkatan kecerdasan logis matematis dapat dilakukan melalui kegiatan-kegiatan yang membantu anak untuk memecahkan beberapa masalah dan penemuan yang baru ditemukan olehnya (Khuluqo, 2014:1). Contohnya Anak mampu mengklasifikasikan benda berdasarkan warna, bentuk, ukuran, mengelompokan berpasangan dan juga menyebutkan bilangan. Anak dapat berpikir untuk membedakan sesuatu yang ditemukannya baik membedakan tinggi, pendek, besar, dan kecil pada benda, membedakan sebab dan akibat terhadap suatu peristiwa dan bahkan anak mengetahui beberapa alasan tentang kondisi lingkungan (cuaca, suhu, dan lain-lain).

Hasil observasi yang dilakukan di RA Golden Rabbani Desa Cibiru Hilir Kecamatan Cileunyi Kabupaten Bandung, pembelajaran pengembangan kognitif pada bidang matematis kurang menarik minat anak dan indikator dalam standar pencapaian perkembangan anak pada poin aspek logis matematis banyak yang belum terlaksana secara maksimal. Hal ini disebabkan karena (1) Proses pembelajaran yang dilakukan masih konvensional, sehingga pembelajaran kurang menarik perhatian anak; (2) kurangnya pengetahuan anak tentang pengenalan angka karena anak sulit memahami konsep bilangan dalam waktu yang singkat; (3) capaian berpikir logis terlihat kurang stabil dan belum merata karena anak belum diberikan suatu kegiatan mandiri untuk mencapai kemampuan tersebut; (4) pembelajaran berhitung untuk meningkatkan logis matematis tidak dikemas semenarik mungkin dan tidak diberikan media yang konkrit, karena anak lebih sulit memahami konsep bilangan secara abstrak.

Upaya untuk dapat membantu anak dalam mengasah kecerdasan logis matematis melalui kegiatan eksplorasi, disini guru mengkolaborasikan antara sains dan matematika seperti mengukur tanaman. Dalam Peraturan Menteri Pendidikan Nasional Republik Indonesia Nomor 58 Tahun 2009 tentang Sistem Pendidikan Anak Usia Dini (Depdiknas, 2007) dinyatakan bahwa anak kelompok B usia 5-6 tahun tingkat pencapaian perkembangan matematisnya telah mampu dalam melakukan eksplorasi dengan berbagai media pembelajaran dan kegiatan.

Langkah dan perencanaan yang akan dilakukan, yaitu membuat suatu cara dan metode pengajaran yang dapat mengatasi kemampuan anak dalam berpikir logis matematis dengan lebih efektif dan kreatif, merancang sebuah pembelajaran melalui permainan yang 
menarik dan sesuai dengan prinsip pembelajaran di RA, tujuannya agar pendidikan anak usia dini dapat terwujud serta anak akan dapat tumbuh dan berkembang secara optimal, menggali potensi anak dan mengembangkan aspek-aspek dalam pertumbuhannya. Oleh sebab itu, masalah penelitian ini dibatasi dengan judul: "Upaya Meningkatan Kecerdasan Logis Matematis Melalui Kegiatan Eksplorasi Mengukur Tanaman” (Penelitian Tindakan Kelas pada Kelompok B di RA Golden Rabbani Desa Cibiru Hilir Kecamatan Cileunyi Kabupaten Bandung)

\section{Metodologi}

Pendekatan dalam penelitian ini menggunakan pendekatan penelitian kualitatif dan kuantitatif atau disebut pendekatan campuran/mixed method. Kajian kualitatif dapat lebih terukur jika didasari oleh kajian data-data kuantitatif valid dan reliable (Hendriana, 2017:23). Metode penelitian menurut Creswell (2017: 6) dengan menggunakan pola Penelitian Tindakan Kelas (PTK) yang dilakukan sebanyak dua siklus. Setiap siklus terdiri dari 4 tahap, yaitu perencanaan, tindakan, observasi dan refleksi. Berdasarkan dari refleksi siklus pertama, dilakukan perbaikan-perbaikan tindakan pembelajaran pada siklus kedua dan dihentikan bila tujuan pembelajaran sudah sesuai dengan tingkat pencapaian perkembangan yang diharapkan.

Data kualitatif digunakan untuk mengetahui proses terlaksananya kegiatan eksplorasi mengukur tanaman yang telah diperoleh dari lembar observasi dan wawancara. Sedangkan data kuantitatif adalah pengukuran untuk menguji hipotesis dengan tujuan menemukan generalisasi dan menekankan pada pengukuran dan analisis sebab dan akibat diantara variabel (Sarosa, 2017:7). Subjek penelitian ini yaitu kelompok B RA Golden Rabbani terdiri dari 27 anak siswa laki-laki ada 12 anak dan siswa perempuan berjumlah 15 anak. Bertempat di Kp. Babakan Cimekar RT.03 RW.06 Desa Cibiru Hilir Kecamatan Cileunyi Kabupaten Bandung. Sumber penelitian diperoleh dari dokumentasi. peneliti melakukan observasi terhadap file-file dokumentasi sekolah, meliputi RPPH, rapot, foto/vidio kegiatan sekolah untuk memperoleh data secara menyeluruh tentang latar belakang sekolah. RPPH (Rencana Pelaksanaan Pembelajaran Harian) sebagai acuan pembelajaran kegiatan eksplorasi mengukur tanaman.

Analisis PTK dapat dilakukan dengan menggunakan analisis kualitatif dan analisis kuantitatif. Analisis kualitatif digunakan untuk menentukan peningkatan proses belajar khususnya berbagai tindakan yang dilakukan oleh guru, sedangkan analisis kuantitatif 
digunakan untuk menentukan peningkatan hasil belajar siswa sebagai pengaruh dari setiap tindakan yang dilakukan guru (wina sanjaya, 2009:106).

Menurut Ditjen Mandas DIKNAS 2010 dalam Dimyanti (2014: 106) menjelaskan bahwa pengukuran pengamatan terhadap anak pada lembar observasi dibagi menjadi empat kriteria penilaian yaitu (1) belum berkembang (BB), (2) mulai berkembang (MB), (3) Berkembang sesuai harapan (BSH), dan (4) berkembang sangat baik (BSB). Analisis data yang dilakukan dalam penelitian ini adalah sebagai berikut:

Analisis data yang dilakukan dalam penelitian ini adalah sebagai berikut:

1. Analisis pengamatan observasi

Analisis hasil pengamatan mengenai gambaran proses penerapan kegiatan eksplorasi mengukur tanaman, serta aktivitas guru selama kegiatan eksplorasi mengukur tanaman menggunakan rumus sebagai berikut:

$$
\text { Persentase }=\frac{\text { Jumlah aktivitas yang tercapai }}{\text { seluruh aktivitas }} \times 100 \%
$$

Setelah diperoleh jumlah aktivitas anak dan guru, kemudian dihitung nilai rataratanya melalui rumus:

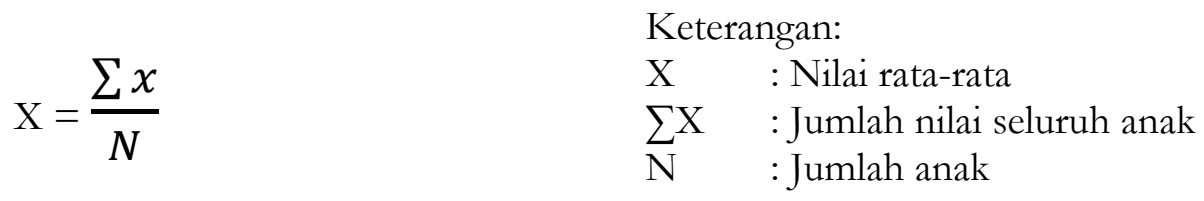

Hasil interprestasi pada kegiatan eksplorasi mengukur tanaman dalam meningkatkan kecerdasan logis matematis anak yaitu sebagai berikut:

Tabel 3.2

Taraf Keberhasilan Tindakan dalam Proses Pembelajaran

\begin{tabular}{|c|c|c|c|}
\hline $\begin{array}{c}\text { Pencapaian Tujuan } \\
\text { Pembelajaran }\end{array}$ & $\begin{array}{c}\text { Skor/ } \\
\text { Nilai }\end{array}$ & Predikat & $\begin{array}{c}\text { Tingkat Keberhasilan } \\
\text { Pembelajaran }\end{array}$ \\
\hline $85-100 \%$ & 3 & Sangat Baik (SB) & Berhasil \\
\hline $65-84 \%$ & 2 & Baik (B) & Berhasil \\
\hline $55-64 \%$ & 1 & Kurang (K) & Tidak Berhasil \\
\hline $0-54 \%$ & 0 & Sangat Kurang (SK) & Tidak Berhasil \\
\hline
\end{tabular}

Sumber: (Aqib, 2009:160)

2. Analisis kecerdasan logis matematis anak melalui unjuk kerja

Analisis kecerdasan logis matematis anak melalui unjuk kerja yaitu mengenai hasil kecerdasan logis matematis anak sebelum melakukan kegiatan eksplorasi mengukur tanaman, dan mengenai hasil kecerdasan logis matematis anak pada setiap akhir siklus pembelajaran eksplorasi mengukur tanaman dengan menggunakan rumus sebagai berikut: 


$$
\mathrm{KLM}=\frac{\text { skor yang dicapai siswa }}{\text { Skor Maksimal }} \times 100
$$

Keterangan:

$\mathrm{KMD}=$ Kecerdasan Logis Matemati

hasil interpretasi pada skala kualifikasi sebagai berikut:

Tabel 2.3

Interval dan Kategori Hasil Belajar

\begin{tabular}{|c|c|c|}
\hline No & Tingkat Penguasaan & Predikat \\
\hline 1 & $80-100 \%$ & Sangat Baik \\
\hline 2 & $70-79 \%$ & Baik \\
\hline 3 & $60-69 \%$ & Cukup \\
\hline 4 & $50-59 \%$ & Kurang \\
\hline 5 & $0-49 \%$ & Kurang Sekali \\
\hline
\end{tabular}

Sumber: Muhhibin Syah, 2010: 223

\section{Hasil dan Diskusi}

Penelitian ini berusaha untuk menjawab permasalahan penelitian tentang kegiatan eksplorasi mengukur tanaman dapat meningkatan kecerdasan logis matematis pada anak kelompok B di RA Golden Rabbani Cibiru Hilir Kabupaten Bandung. Berdasarkan hasil pengolahan data yang terkumpul dengan teknik observasidan unjuk kerja diperoleh sebagai berikut:

1. Kecerdasan logis matematis anak sebelum diterapkan kegiatan eskplorasi mengukur tanaman pada kelompok B di RA Golden Rabbani Kabupaten Bandung

Kecerdasan logis matematis sebelum tindakan memperoleh nilai rata-rata sebesar 67,78 termasuk kategori cukup. Masih banyak anak yang belum bisa memahami konsep bentuk, ukuran, warna melalui permainan puzæle (Hamalik, 2011), anak masih kesulitan membedakan gambar secara utuh ketika gambar diacak dan harus menyusunnya. Rekapitulasi hasil unjuk kerja anak dalam kecerdasan logis matematis pada pra tindakan dijelaskan berdasarkan jumlah anak yang memperoleh nilai dari kriteria baik sebanyak 10 orang dan kriteria cukup 17 orang. pada saat pra tindakan dalam setiap kegiatan menyelesaikan puzzle (menganyam), menonton film animasi (bercerita) pada anak kelompok B di RA Golden Rabbani memperoleh rata-rata kriteria cukup dan belum mencapai tujuan yang diharapkan kedepannya.

Kegiatan pembelajaran yang dilakukan pra tindakan untuk meningkatkan kecerdasan logis matematis sebelum diterapkan tindakan kegiatan eksplorasi mengukur tanaman yaitu berupa kegiatan menyelesaikan puгzle tanaman, mengamati gambar tanaman 
melalui film animasi, mengenal angka bilangan 1-10 berdasarkan gambar dan mengklasifikasikan bentuk, warna, ukuran geometri pada gambar. Seperti yang diungkapkan oleh risang melati (Rozi, 2015) mengemukakan tentang cara memahami anak-yang memiliki kecerdasan logika-matematika yaitu:

a. Mengelompokan benda yang diketahui anak berdasarkan bentuk, warna, ukuran, dan jenis.

b. Mengingat benda mati, hewan, tanaman yang mempunyai warna, bentuk atau ukuran atau memiliki ciri-ciri tertentu.

c. Menceritakan perasaan dalam hatinya tentang peristiwa yang terjadi jika: warna dicampur, proses pertumbuhan tanaman (biji-bijian, umbi-umbian, batang-batangan) balon ditiup lalu dilepaskan, benda-benda dimasukan kedalam air, apakah terapung, melayang, tenggelam dan membedakan bermacam-macam rasa, bau dan suara.

d. Menyebutkan pola hubungan seperti konsep depan-belakang-tengah, atas-bawah, luardalam, pertama-terakhir-diantara, keluar-masuk, naik-turun, maju-mundur

2. Proses Penerapan Kegiatan Eksplorasi Mengukur Tanaman Untuk Meningkatkan Kecerdasan Logis Matematis Anak pada kelompok B di RA Golden Rabbani Kabupate Bandung

Peningkatan kecerdasan logika matematika pada anak salah satunya dapat menggunakan aktivitas bermain, guru dapat memberikan permainan yang disesuaikan dengan kebutuhan anak, karena melalui bermain anak akan memperoleh pengetahuan yang dapat mengembangkan kemampuan dalam dirinya (Yuliani, 2009:144). Aktivitas guru yang dilakukan di RA Golden Rabbani dilakukan dengan 4 kegiatan dimulai kegiatan pembiasaan seperti membaca Iqra, baris-berbaris), kegiatan inti, istirahat dan kegiatan penutup.

Proses pembelajaran dengan melaksanakan kegiatan eksplorasi mengukur tanaman untuk meningkatkan kecerdasan logis matematis anak, dapat dilihat dari aktivitas yang dilakukan oleh guru dan anak. Berikut gambaran aktivitas guru dan anak selama pembelajaran.

1. Aktivitas Guru dan Anak pada Siklus I

Siklus I terdiri dari dua tindakan. Tindakan pertama dilaksanakan pada tanggal 08 Agustus 2019 dan tindakan kedua pada tanggal 09 Agustus 2019.

a. Perencanaan

Tahap penyusunan rencana tindakan pada siklus ini yaitu: 
1) Mendiskusikan susunan RPPH (Rencana Pelaksanaan Pembelajaran Harian). Adapun rencana pelaksanaan kegiatan pembelajaran di siklus pertama menggunakan tema tanaman, dengan sub tema tanaman sayur pada tindakan pertama dan kedua.

2) Mempersiapkan lembar observasi aktivitas guru berdasarkan langkah-langkah yang harus dilakukan selama pembelajaran

3) Mempersiapkan lembar observasi mengenai kecerdasan logis matematis anak pada kegiatan eksplorasi mengukur tanaman

4) Mempersiapkan alat dan bahan yang akan digunakan dalam pembelajaran, yaitu: kertas origami, gambar tanaman daun bawang, kertas HVS, TV.

5) Mempersiapkan film animasi tentang tanaman buah dan sayur.

b. Tindakan

Pelaksanaan pembelajaran pada siklus I mempunyai 3 tahap, yaitu kegiatan awal, kegiatan inti dan kegiatan penutup. Kegiatan awal dimulai pada pukul 07.00 sampai 08.00 dengan kegiatan berbaris, berdo'a, satu per satu anak-anak membaca iqra, dilanjutkan dengan hafalan do'a sehari-hari. Guru menanyakan kabar anak, mengabsen kehadiran anak dan menyiapkan bahan-bahan yang dipakai di kegiatan inti. Setelah itu, guru melakukan tanya jawab mengenai tema pada hari itu. Kegiatan inti guru melanjutkan kegiatan belajar eksplorasi mengukur tanaman. Langkah-langkah dalam kegiatan eksplorasi mengukur tanaman yaitu

1) Guru menjelaskan tentang tanaman sesuai dengan tema yang diajarkan.

2) Guru menjelaskan alat dan bahan yang akan digunakan.

3) Guru melakukan analisis dengan menampilkan film animasi

4) Anak melakukan eksplorasi mengukur tanaman

5) Anak menceritakan kembali kegiatan eksplorasi mengukur tanaman

6) Guru memberikan penguatan kegiatan yang telah dilakukan.

Kegiatan penutup guru melakukan evaluasi tentang pembelajaran yang sudah disampaikan kepada anak.

\section{c. Observasi}

Observasi ini berdasarkan data yang diperoleh dari lembar observasi dan dokumentasi. Hasil observasi aktivitas guru pada siklus I tindakan pertama sebesar 69,56\%, dan tindakan kedua 78,26\% dengan nilai rata-rata sebesar 73,91\% termasuk kualifikasi baik, dan aktivitas anak pada tindakan pertama sebesar pada siklus II tindakan pertama sebesar 
$68,61 \%$ dan tindakan kedua $73,48 \%$, nilai rata-rata sebesar $71,041 \%$ termasuk kualifikasi baik.

\section{d. Refleksi}

Pada kegiatan pembelajaran di siklus I terdapat beberapa temuan diantaranya guru belum dapat mengkondisikan anak pada saat penyampaian tema, guru belum dapat mengkondisikan dan membimbing anak pada saat eksperimen dan anak belum dapat menceritakan kembali kegiatan yang telah dilakukan. Untuk memperbaiki kekurangan yang terdapat pada siklus I, maka peneliti bersama guru kelompok B mengambil kesimpulan dan kesepakatan untuk melaksanakan siklus II.

2. Aktivitas Guru dan Anak pada Siklus II

Siklus II terdiri dari dua tindakan. Tindakan pertama dilaksanakan pada tanggal 12 Agustus 2019 dan tindakan kedua pada tanggal 13 Agustus 2019.

a. Perencanaan

Tahap perencanaan tindakan pada siklus ini yaitu:

1) Memperbaiki kembali RPPH (Rencana Pelaksanaan Pembelajaran Harian). Adapun rencana pelaksanaan kegiatan pembelajaran di siklus kedua menggunakan tema lingkungan, dengan sub tema kebun pada tindakan pertama dan kedua dengan melakukan revisi pada siklus I

2) Mempersiapkan lembar observasi aktivitas guru berdasarkan langkah-langkah yang harus dilakukan selama pembelajaran

3) Mempersiapkan lembar observasi mengenai kecerdasan logis matematis anak pada kegiatan eksplorasi mengukur tanaman

4) Mempersiapkan alat untuk mendokumentasikan kegiatan anak eksplorasi megukur tanaman yakni kamera dan handphone.

b. Tindakan

Pelaksanaan pembelajaran pada siklus II mempunyai 3 tahap, yaitu kegiatan awal, kegiatan inti dan kegiatan penutup. Kegiatan awal dimulai pada pukul 07.00 sampai 08.00 dengan kegiatan berbaris, berdo'a, satu per satu anak-anak membaca iqra, dilanjutkan dengan hafalan do'a sehari-hari. Guru menanyakan kabar anak, mengabsen kehadiran anak dan menyiapkan bahan-bahan yang dipakai di kegiatan inti. Setelah itu, guru melakukan tanya jawab mengenai tema pada hari itu. Kegiatan inti guru melanjutkan kegiatan belajar mengenai sains melalui eksperimen. Langkah-langkah dalam penerapan metode eksperimen pada pembelajaran sains yaitu: 
1) Guru menjelaskan tentang tanaman sesuai dengan tema yang diajarkan.

2) Guru menjelaskan alat dan bahan yang akan digunakan.

3) Guru melakukan analisis dengan menampilkan film animasi

4) Anak melakukan eksplorasi mengukur tanaman

5) Anak menceritakan kembali kegiatan eksplorasi mengukur tanaman

6) Guru memberikan penguatan kegiatan yang telah dilakukan.

Kegiatan penutup guru melakukan evaluasi tentang pembelajaran yang sudah disampaikan kepada anak.

c. Observasi

Observasi ini berdasarkan data yang diperoleh dari lembar observasi dan dokumentasi. Hasil observasi aktivitas guru pada siklus II tindakan pertama sebesar pada siklus II tindakan pertama sebesar $86,95 \%$ dan tindakan kedua $100 \%$ dengan nilai rata-rata sebesar 95,46\% termasuk kualifikasi sangat baik dan berhasil. Gambaran peningkatan hasil observasi aktivitas guru dari siklus I sampai siklus II dapat dilihat berikut ini.



Grafik 4.2

Peningkatan Aktivitas Guru Dari Siklus I Sampai Siklus II

Hasil observasi aktivitas anak pada siklus II tindakan pertama dan kedua sebesar 85,96 termasuk pada kualifikasi sangat baik Gambaran peningkatan hasil observasi aktivitas anak dari siklus I sampai siklus II dapat dilihat berikut ini. 


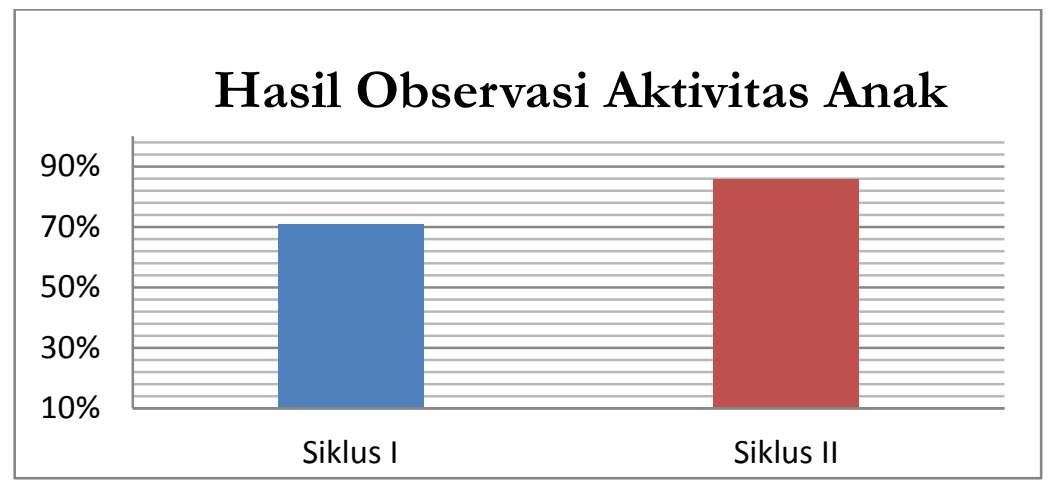

d. Refleksi

Grafik 4.3

Peningkatan Aktivitas Anak Dari Siklus I Sampai Siklus II

Refleksi pada siklus II dilakukan sebagaimana hasil dari siklus I. Dari aspek temuan refleksi siklus I sudah tidak ada lagi temuan koreksi, hal ini menunjukan bahwa penerapan kegiatan eksplorasi mengukur tanaman untuk meningkatkan kecerdasan logis matematis pada kelompok B di RA Golden Rabbani Desa Cibiru Hilir berjalan dengan baik maka penelitian berakhir pada siklus II.

3. Kecerdasan Logis Matematis Anak Setelah Menerapkan Kegiatan Eksplorasi Mengukur Tanaman pada kelompok B di RA Golden Rabbani Kabupate Bandung

Kecerdasan logis matematis setelah diterapkan kegiatan eksplorasi mengukur tanaman diperoleh data hasil observasi aktivitas guru dan anak selama pembelajaran, diperoleh data hasil unjuk kerja pada kecerdasan logis matematis anak. Pada siklus I tindakan pertama sebesar $72,59 \%$ dan tindakan kedua $78,88 \%$ dengan nilai rata-rata sebesar 75,35\% termasuk kriteria baik. Pada siklus II tindakan pertama dan tindakan kedua 89,17\% termasuk kriteria sangat baik. Pelaksanaan kegiatan eksplorasi dilakukan melalui kegiatan mengklasifikasikan, mengamati, memahami, mengingat dan mengukur tanaman

Dari hasil analisis data di atas terjadi peningkatan kecerdasan logis matematis anak pada kegiatan eksplorasi mengukur tanaman dari penelitian pra siklus, siklus I dan siklus II. Perbandingan peningkatan kecerdasan logis matematis anak pada kegiatan eksplorasi mengukur tanaman pra siklus, siklus I dan siklus II dapat digambarkan sebagai berikut: 


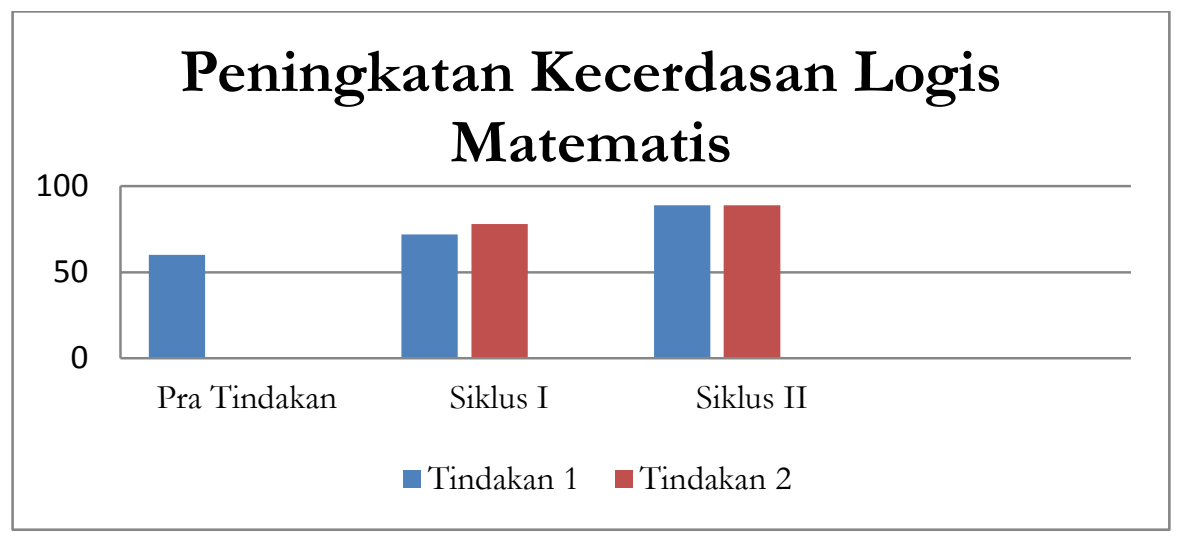

Grafik 4.4

Peningkatan Kecerdasan Logis Matematis setiap Siklus

Dari hasil observasi dan unjuk kerja tersebut menunjukkan bahwa kegiatan eksplorasi mengukur tanaman untuk meningkatkan kecerdasan logis matematis anak pada kelompok B di RA Golden Rabbani Cibiru Hilir Kabupaten Bandung telah berhasil dilaksanakan. Hasil unjuk kerja pra siklus mengenai kecerdasan logis matematis anak diperoleh rata-rata sebesar 67,77 dengan kriteria kurang. Keadaan ini menunjukkan bahwa kecerdasan logis matematis anak berada pada kualifikasi kurang.

Peningkatan kecerdasan logika matematika pada anak salah satunya dapat menggunakan aktivitas bermain, guru dapat memberikan permainan yang disesuaikan dengan kebutuhan anak, karena melalui bermain anak akan memperoleh pengetahuan yang dapat mengembangkan kemampuan dalam dirinya (Yuliani, 2009:144).

Pada aktivitas guru di siklus I diperoleh rata-rata sebesar 69,56\%, dan tindakan kedua $78,26 \%$ dengan nilai rata-rata sebesar 73,91\% termasuk kualifikasi baik. Keadaan ini menjelaskan bahwa dalam penerapan kegiatan eksplorasi, guru belum mampu mengkondisikan anak dan umumnya metode ini jarang dilakukan disekolah pada anak.

Seperti pendapat Piaget perkembangan yang mendukung kecerdasan otaknya meliputi permainan yang mengasah kemampuan dalam pemecahan masalah, mengeksplorasi pikiran, pengenalan pola, eksperimen, dan pengenalan bilangan. kegiatan bermain yang bertujuan melakukan eksplorasi objek-objek pada benda dan lingkungan sekitar anak dapat meningatkan kecerdasan logis matematis (Piaget \& Hunt, 2011)

Pada siklus II terjadi peningkatan yaitu aktivitas guru diperoleh rata-rata sebesar $86,95 \%$ dan tindakan kedua $100 \%$ dengan nilai rata-rata sebesar $95,46 \%$ termasuk kualifikasi sangat baik dan berhasil. Ketercapaian pada siklus II ini dikarenakan metode 
yang diterapkan oleh guru dengan kegiatan eksplorasi mengukur tanaman sudah dapat dilakukan dengan baik sehingga berpengaruh pada aktivitas anak menjadi lebih baik. Penutup

Kecerdasan Logis Matematis pada kelompok B di RA Golden Rabbani Cibiru Hilir Kabupaten Bandung sebelum melaksanakan kegiatan eksplorasi mengukur tanaman diperoleh nilai rata-rata sebesar 69,77 dengan kriteria kurangi. Penerapan kegiatan eksplorasi mengukur tanaman dalam meningkatkan kecerdasan logis matematis anak pada kelompok B di RA Golden Rabbani Cibiru Hilir Kabupaten Bandung pada setiap siklus mengalami peningkatan. Aktivitas guru pada siklus I diperoleh nilai rata-rata sebesar sebesar 69,56\%, dan tindakan kedua 78,26\% dengan nilai rata-rata sebesar 73,91\% termasuk kualifikasi baik, pada siklus II tindakan pertama sebesar 86,95\% dan tindakan kedua $100 \%$ dengan nilai rata-rata sebesar 95,46\% termasuk kualifikasi sangat baik dan berhasil. Perhitungan hasil pengamatan pada penilaian aktivitas anak pada siklus I tindakan pertama sebesar 68,61\% dan tindakan kedua 73,48\%, nilai rata-rata sebesar 71,041\% termasuk kualifikasi baik. Pada siklus II tindakan pertama dan kedua sebesar 85,96 termasuk pada kualifikasi sangat baik. Perhitungan pada penilaian unjuk kerja anak sebelum dilakukan tindakan sebesar 67,77\% termasuk kriteria cukup, penilaian unjuk kerja anak pada siklus I tindakan pertama sebesar $72,59 \%$ dan tindakan kedua 78,88\% dengan nilai rata-rata sebesar $75,35 \%$ termasuk kriteria baik. Pada siklus II tindakan pertama dan tindakan kedua 89,17\% termasuk kriteria sangat baik. Pelaksanaan kegiatan eksplorasi dilakukan melalui kegiatan mengklasifikasikan, mengamati, memahami, mengingat dan mengukur tanaman. Bagi peneliti yang akan melakukan penelitian tindakan kelas dengan melakukan kegiatan eksplorasi mengukur tanaman, hendaknya mempertimbangkan kembali kegiatan yang akan dilakukan. Materi yang akan disampaikan kepada anak usia dini harus disesuaikan dengan kebutuhan anak dan lebih disederhanakan kembali serta media yang akan digunakan lebih bervariatif

\section{Daftar Pustaka}

Andayani, A. M. (2013). Pendidikan Karakter Persfektif Islam, Bandung: PT Remaja Rosdakarya.

Arikunto, S. S. (2009). Penelitian Tindakan Kelas, Jakarta: PT Bumi Aksara.

Aqib, Z. (2009). Penelitian Tindakan Kelas. Bandung: CV. Yrama Widya

Mursyid. (2015). Belajar dan Pembelajaran PAUD. Bandung: Rosdakarya. 
Mursyid. (2017). Pengembangan dan pembelajaran PAUD, Bandung: PT Remaja Rosdakarya Sa'dun, A. (2019). Instrumen Perangkat Pembelajaran, Bandung: Remaja Rosdakarya

Suryana, D. (2016). Pendidikan Anak Usia Dini "Stimulasi dan Aspek Perkembangan anak", Jakarta: penerbit kencana.

Sarosa, s. (2012). Penelitian Kualitatif dasar-dasar, Jakarta: PT Indeks

Syah, Muhibbin. (2013). Prosedur penelitian suatu pendekatan praktik, Jakarta: Rineka Aksara

Trianto. (2010). Model Pembelajaran Terpadu . jakarta : PT Bumi Aksara.

Yaumi, M. (2012). Cara Mengembangkan Berbagai Komponen Kecerdasan, Jakarta timur: Dian Rakyat

Yuliani (2009). Konsep Dasar Pendidikan Anak Usia Dini. Jakarta Barat: PT. Macanan Jaya Cemerlang 